\title{
Indledning
}

\section{Lighed og
Anerkendelse \\ Lighed og
Anerkendelse}

\section{OG CHRISTINA FIIG}

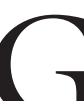

eorge Orwells bog

Animal Farm: (Kammerat Napoleon) udgør et lidt slidt ikon og en metafor over uligheders dynamik. At nogle er mere lige end andre, er gledet ind i sproget som en metafor, når uligheder og uligestilling drøftes. I tråd med Orwell understreger et kønsperspektiv kompleksiteten i en lighedsdiskussion og rejser bl.a. spørgsmål om, hvilke typer af (u)ligheder for kvinder og mænd, som er legitime i en given kontekst. Køn må forstås i samspil med andre forskelssættende kategorier som etnicitet, klasse, seksualitet og generation, når metaforen om lighed skal bringes ind i samtiden. Når et begreb som anerkendelse indgår i dette samspil, øges kompleksiteten yderligere. Tænk bare på den europæiske tørklædedebat, homoseksuelles ret til børn eller skandinaviske feministers krav om anerkendelse af kropslig integritet i det, der er italesat som verdens mest ligestillede samfund. Kernen her er, hvilke sociale og kulturelle karakteristika for grupper af individer og enkeltpersoner som vinder anerkendelse el- 
ler netop ikke gør. Og hvilke typer af økonomisk omfordeling, som dette kræver.

De nordiske samfund er de sidste årtier gradvist blevet (italesat som) mere heterogene, hvilket har aktualiseret debatten om lighed og spørgsmålet om anerkendelse af forskellige typer af forskelligheder. Både i analyser af samfundsfænomener og i teoretiske debatter. Anerkendelse forstås her bredt som ligeværdighed i form af respekt og værdsættelse. Spændingen og dynamikken mellem lighed og anerkendelse er omdrejningspunkt for dette temanummer.

Begrebet 'anerkendelse' kommer rejsende til et teoretisk terræn og til en empirisk kontekst, der bygger på en underliggende norm om lighed. Dets ankomst udfordrer derfor 1990'ernes opfattelse af de 'nordiske verdensmestre i ligestilling', og den genåbner en diskussion om lighed og ulighed, forskel og identitet, som tidligere var formuleret i delvist emancipatoriske termer omkring forskellige strategier for frigørelse eksempelvis i tidligere diskussioner inden for kønsforskningen om lighed versus forskel (Scott 1988, Bacchi 1999). Vores afsæt er både en empirisk nysgerrighed i forhold til debatten om anerkendelse - hvorledes den forskyder allerede eksisterende debatter om lighed og ligestilling i Norden- og en drillende finger i siden på nordisk kønsforskning med spørgsmålet om, hvad forskningen kan anvende feltet mellem lighedsog anerkendelse til.

Konflikter om lighed og anerkendelse af forskelligheder baseret på køn, etnicitet, klasse eller seksualitet giver ekko i artiklerne nedenfor. Nogle forskere hævder, at de nordiske velfærdsstater er bedre til at håndtere kønsmæssige end klassemæssige spørgsmål eksempelvis den svenske politolog Walter Korpi (2002), mens andre, herunder den danske historiker Anna-Birte Ravn i dette temanummer argumenterer for, at den danske velfærdsstat frem til 1975 prioriterede klassemæssig omfordeling højere end omfordeling mellem kønnene.

Det er centralt at tænke forholdet mel- lem politikker formuleret med henblik på at skabe større lighed igennem en prisme af anerkendelse, og overveje, hvordan vi som kritiske samfundsforskere forholder os teoretisk og empirisk til den rakke af nye, sociale kampe, som er blevet tydeligere i Norden. Eksempelvis kampen om magten og betydningen af ligestilling i det private erhvervslivs top, som det diskuteres i artiklen af de norske samfundsforskere Hege Skjeie og Mari Teigen. Og kampen om anerkendelse af et kønsperspektiv og kvinders rettigheder i fagbevægelsen, som den danske kultursociolog Lise Lotte Hansen diskuterer nedenfor. Det er også centralt at sondre mellem forskellige arenaer for disse sociale kampe som fx parlament, domstole, arbejdsmarkedet, familien og civilsamfundets organiseringer. Andre arenaer kan udgøres af lokale, nationale og internationale offentligheder, hvor forhandling om lighed og anerkendelse pågår (Fiig 2003).

\section{TEORETISKE PERSPEKTIVER -}

\section{ANERKENDELSE OG LIGHED}

To eksponenter for anerkendelsesteori er den politiske teoretiker og spydspids i amerikansk, politisk (feministisk) teori professor Nancy Fraser, New School for Social Research, New York, USA og den tyske filosof Axel Honneth, efterfølger til Habermas' professorat i Frankfurt. ${ }^{1}$ Disse to udgav i 2003 bogen Redistribution or Recognition? A Political-Philosophical Exchange. Deres positioner udgøres af en kritisk social-liberalistisk position (Honneth) versus en feministisk, post-strukturalistisk og socialistisk position (Fraser). Bogen diskuterer anerkendelsesprincipper og deres forhold til bl.a. lighed, etik og retfærdighed. Fraser har haft en stor indflydelse på nordiske samfundsvidenskabelig kønsforskning, hvilket dette temanummer også afspejler.

På linje med den nordiske diskussion forholder Nancy Fraser sig kritisk til traditionen omkring anerkendelse og påpeger nødvendigheden af at bibeholde et element af 
tidligere retfærdighedsteori og dets fokus på fordelingsmæssig lighed. Omfordelingsdiskussionen er aktualiseret på dansk grund med årets ministerielle melding om uligheders samfundsmæssige dynamik. Frasers teori er en teoretisk syntese af et fokus på fordelingsmæssig lighed og anerkendelse. På denne måde står hun mellem to paradigmer og er en central teoretiker for en diskussion af forholdet mellem anerkendelse og lighed - også i et klasseperspektiv.

Teoretisk og normativt kan der således identificeres et nyt fokus på forskellighed og ligeværdighed i den angloamerikanske debat og i den nordiske samfunds- og kønsforskning, Anerkendelse og lighed er forskellige begreber med hver deres etymologi og forskellige kontekstuelle betydninger, hvorfor de må analyseres konkret, ligesom den danske politolog Birte Siim anbefaler i sin vending mod mere kontekstuel teori og kontekstfølsomme begreber (2004). En pointe er her, at det er centralt at reflektere over vores tænknings bundethed i en given lokalitet og en bestemt institutionel kontekst (som eksempelvis en nordisk, velfærdsstatslig ramme), og brugen af importerede, teoretiske begreber, der ofte 'rejser' langt.

Empirisk har særligt Frasers tilgang inspireret flere komparative analyser af den nordiske velfærdsstatsmodel i et ligheds- og ligestillingsperspektiv (Dahl 2004, Hobson 2003, Lindvert 2002). Dette temanummer kan stimulere en metodiske diskussion omkring anvendelse af hendes analytiske begreber og introducere en mere overordnet diskussion om typer af feministisk kritik foranlediget af bl.a. Frasers øgede interesse for eksplicitering og begrundelse af de kritiske standarder, der ligger til grund for hendes forskning. Det er netop denne diskussion, som tages op i den norske filosof Cathrine Holsts artikel.

\section{ANERKENDELSE, LIGESTILLINGSPOLITIK OG FEMINISTISK KRITIK}

Temanummeret åbner med et interview med Nancy Fraser. Fordelingsmæssige kampe vedrører socioøkonomiske forhold som bl.a. indkomst, ejendom, uddannelse, sundhed og dødelighed (1997). Anerkendelse forstår hun specifikt som social status dvs. som den status som individuelle gruppemedlemmer tillægges (eller frakendes) som fuldgyldige deltagere i social interaktion. Med formuleringen af 'fuldgyldige deltagere' vitaliserer Fraser den britiske samfundsforsker T. H. Marshall og hans medborgerskabsopfattelse (2003), idet fokus er på sammenhængen mellem medborgerskabets 3 elementer. Dvs. hvordan de civile og sociale aspekter understøtter den politiske deltagelse og representation.

Inspireret af Frasers tilgang retter Lise Lotte Hansen fokus på den nordiske velfærdsstats model og fagbevægelsen. Skal vi fortsætte den skandinaviske vej? Eller skal der i stedet satses på særlige rettigheder til eksempelvis enlige mødre og kvinder i fagbevægelsen? Særlige rettigheder, der måske samtidigt reproducerer en stigmatiserende position? Hun analyserer muligheden for og resultaterne af forskellige strategier i fagbevægelserne i hhv. England og Danmark og nødvendigheden af at gentænke det ligestillingspolitiske felt, så politiske initiativer ikke reproducerer en given kønsorden via en ureflekteret tilgang til det 'normale'.

Hege Skjeie og Mari Teigen analyserer den norske kønsdebat på baggrund af både kvantitative og kvalitative data. I artiklen problematiseres den norske 'rejse-metafor', der bidrager til at fremstille ligestilling som en linexr proces med skridt frem og tilbage på vej mod målet og som et samfundsmæssigt konsensusfelt, der bygger på bestemte opfattelser af frellesskab og det nationale. Den norske elite og befolknings holdninger til ligestilling undersøges ud fra et 'begrundelsesrepertoire' i form af en typologi af argumenter for ligestilling. Denne omfatter et argument om ligestilling som en rettighed til deltagelse, et om ressourcer/nytte ('det betaler sig', 'kvinder har noget at bi- 
drage med') og et om interesser. Artiklens afsæt er rettigheds-deltagelsesargumentet. Forfatterne problematiserer nytteargumentet ved at pointere, at det kan bidrage til at reducere kvinder til midler for andre organisations- og samfundsmæssige mål.

Anna-Birte Ravn tager feltet op omkring skattepolitik ud fra en køns- og anerkendelsesoptik. Hun påviser, hvordan skattelovgivningen i Danmark i perioden 19031970 både fordelingsmæssigt og kulturelt begunstigede $x$ gtemandens status. I perioden skærpedes bl.a. dilemmaet mellem fordelingsmæssig lighed mellem kvinder og mænd, og kulturel anerkendelse af kvindearbejdet i hjemmet. Skattepolitikken formåede i denne periode ikke at bidrage til en transformation af kønsrelationerne på trods af vigtige, skattepolitiske ændringer som bl.a. opgivelse af sambeskatningen. Artiklen påviser desuden et dilemma mellem lighed og anerkendelse i forhold til ligeværdighed mellem forskellige familietyper. Endelig diskuteres Dansk Kvindesamfunds og socialdemokratiets rolle.

Frasers teori er normativ og kritisk i den forstand, at den er et indlæg i den kontinuerlige diskussion af retfærdighed og retfærdige institutioner. Netop hendes kritiske position er omdrejningspunktet for Cathrine Holst. Hun påviser, hvordan Fraser oprindeligt argumenterede for 'social kritik uden filosofi', men nu er eksponent for en nærmest habermasiansk tilgang, som bygger på behovet for en moralfilosofisk begrundet kritik. Og at dette skifte har betydning for den enkelte, feministiske forsker, når der skal produceres andet end blot overfladisk forskning.

Endelig afslutter temanummeret med en kritisk kommentar af den dansk-svenske politolog Drude Dahlerup til Hege Skjeie og Mari Teigens artikel. Heri diskuterer hun to forskellige politiske argumentationsmåder omkring ligestilling og kvinders deltagelse, som de formuleres i argumenter om nytte og om retfærdighed.

\section{Noter}

1. Anerkendelsesteorien har andre, prominente fortalere som Charles Taylor (1994), Iris Marion Young (1990) og Jodi Dean (1996).

\section{LITTERATUR:}

- Bacchi, Carol (1999) Women, Policy and Politics the Construction of Policy Problems. Sage, London. - Dahl, Hanne Marlene (2004) "A View from the Inside: Recognition and Redistribution in the Nordic Welfare State from a Gender Perspective", Acta Sociologica, 47 (4): 325-337.

- Dean, Jodi (1996) Solidarity of Strangers. Feminism after Identity Politics. Berkeley, University of California Press.

- Fiig, Christina (2003) A Feminist Public Sphere. An Analysis of the Habermasian Public Sphere in a Danish Gender Political Context, ph.d-afhandling, Aalborg Universitet

. Fraser, Nancy (1997) Justice Interruptus. Routledge, London.

- Fraser, Nancy og Axel Honneth (2003) Redistribution or Recognition? A Political-Philosophical Exchange. Verso, London.

. Hobson, Barbara (2003) "Recognition Struggles in Universalistic and Gender Distinctive Frames", i B. Hobson (red.) Recognition Struggles and Social Movements. Oxford University Press, Oxford.

- Korpi, Walter (2002) Velfardsstat og socialt medborgerskab. Danmark i et komparativt perspektiv 1930-1995. Magtudredningen, Århus.

- Lindvert, Jessica (2002) Feminism som politik. Borea Bokforlag, Umeå.

- Marshall, T.S (2003) Medborgerskab og social klasse. Hans Reitzels forlag, København.

- Scott, Joan W. (1988) "Deconstructing Equalityversus-Difference", Feminist Studies, 14 (1): 3350 .

- Siim, Birte (2004): "Towards a Contextual and Gender Sensitive European Political Science", European Political Science, 3 (2): 97-101.

- Taylor, Charles (1994) "The Politics of Recognition", i A. Gutman (red.) Multiculturalism, Princeton University Press, New Jersey.

- Young, Iris Marion (1990) Justice and the Politics of Difference. Princeton University Press, New Jersey.

Hanne Marlene Dahl, lektor, Institut for samfundsvidenskab og erhvervsøkonomi, RUC og Christina Fiig, adjunkt, Center for Kønsforskning, Institut for Historie, Internationale Studier og Samfundsforhold, Aalborg Universitet 